\title{
PLANT VARIETY PROTECTION LEGISLATION: OVERVIEW OF AN INDIAN AND AFRICAN PERSPECTIVE
}

\author{
Available online at www.ijdra.com \\ REVIEW ARTICLE \\ ${ }^{1}$ Mathur V*, ${ }^{2}$ Musyuni P. \\ ${ }^{1}$ Registered Patent Agent and Assistant Professor, Lachoo Memorial College of Science and \\ Technology, Jodhpur, Rajasthan - 342003, India. \\ ${ }^{2}$ Associate, Remfry \& Sagar, Gurgaon, India \\ *Corresponding Author's E-mail: vipinmathur75@gmail.com
}

\begin{abstract}
:
Plant Variety Protection (PVP) legislation provide for the establishment of an effective system for protection of plant varieties, the rights of farmers and plant breeders to encourage the development of new varieties of plants. The TRIPS agreement has established the minimum standards for protection and enforcement of plant varieties by the each member country. TRIPS left to each country's discretion whether to protect new plant varieties by means of patent or by effective sui generis system or by any combination thereof. In India and Africa protection to new plant varieties is provided through PVP Acts. This paper discusses the salient features of the PVP laws of these countries. The PVP law affects the agriculture based economy in countries such as India and Africa in a significant way, thus, economic implications of this law are discussed herein.
\end{abstract}

Keywords: Plant variety, biological resources, WTO, TRIPS, CBD, UPOV

\section{Introduction:}

Plant varieties protection in form of plant breeders' rights has been in existence in industrialized countries for a long time.

The fundamental hypothesis behind granting legal protection to plant varieties is to support and encourage commercial plant breeders to invest their resources for improving upon the existing plant varieties. Thus, Intellectual property rights (IPRs) in plant varieties provides an assurance concept to breeders that they will be able to overcome the risks and costs of experiment satisfying a value-added innovation which is based upon an underlying biological resource (1).

The Convention of the International Union for Protection of New Varieties of Plants (UPOV), first adopted in 1961 and has been subsequently revised in 1972, 1978 and 1991, has recognized the need for protecting varieties of plants to safeguard the interest of breeders.

The concerns in the issue subsequently led to the adoption of two United Nations binding international treaties, the Convention on
Biological Diversity (CBD), the first global agreement on the conservation and sustainable use of biological diversity, signed at the 1992 Earth Summit in Rio de Janeiro, and the International Treaty on Plant Genetic Resources for Food and Agriculture (PGRFA), adopted on 3 November 2001 under the auspices of the FAO, which recognizes the enormous contribution that farmers and their communities have made and continue to make to the conservation and development of genetic resources.

The WTO agreement on Trade Related Aspects of Intellectual Property Rights (TRIPs Agreement), one of the results of the Uruguay Round, states that WTO members “... shall provide for the protection of plant varieties either by patents or by effective sui generis system of its own kind or by any combination thereof."

The TRIPs agreement provides flexibility in its provision to each member country whether 
they protect new plant varieties either by means of patent protection or either by sui generis system or combination of both. TRIPS contain no further standard as to what constitutes an effective sui generis system, nor does it mention UPOV (2). Thus, developing countries are not obliged to provide for the protection of plant varieties under patents or to comply with UPOV provisions; instead, they may prefer to develop their own sui generis system of protection.

TRIPs agreement in its Article 27 provides wider implications for plant variety protection and food security. This article focuses on all necessary issues that the patent protection shall be available for any invention, in both forms, whether product or process, in all fields of technology. However, certain exemptions are granted under TRIPs Article 27.3(b) which states that members may also exclude from patentability 'plants and animals other than micro-organisms, and essentially biological processes for the production of plants or animals other than non-biological and microbiological processes. However, members are directed to the agreement for protection of plants varieties either by patents or an effective sui generis system or by any combination thereof.' The term sui generis is, therefore, is a concern matter of both broad and narrow interpretations. The option of sui generis under TRIPs Article 27.3(b) provides sufficient flexibility for countries to design a system that best fits their circumstances and meets their goals and objectives. Accordingly, impact \& scope of IPRs is needs to be extended and existing IPRs regimes are being strengthened in the member countries who advocate for strong IPR regime. On the other hand many developing countries have opted for a sui generis (of its own kind) system of intellectual property protection to comply with the requirements of TRIPs Article 27.3(b).

The obligation to introduce plant varieties protection in developing countries is a novelty for all. It will bring fundamental changes to their legal system and constitute significant departure from previous practices which generally empathized the free sharing of knowledge at all levels. Moreover, it affects access to propagating material (seeds) by local or rural communities where most population meets their basic needs largely from traditional farming. Farming communities have a well established practice of saving, exchanging and replanting seeds which may be restricted under plant breeders' rights.

\section{TRIPS Standards for protection of Plant varieties}

The TRIPs agreement has established the minimum standards for protection and enforcement of intellectual property rights. As laid out in Article 7, which indicated the TRIPs agreement objectives (3), "the protection and enforcement of intellectual property rights should contribute to the promotion of technological innovation and to the transfer and dissemination of technology, to the mutual advantage of producers and users of technological knowledge and in a manner conducive to social and economic welfare, and to a balance of rights and obligations."

Article 27.3(b) of the TRIPs agreement provides provisions for the WTO members to exclude from patentability "plants and animals other than micro-organisms, and essentially biological processes for the production of plants or animals other than non-biological and micro-biological processes" in order to avoid conflicting issues. However, this provision makes it obligatory that WTO members "provide for the protection of plant varieties either by patents agreement or by an effective sui generis system or by any combination thereof."

\section{Scope of the Protection}

It should be noted that while the TRIPs agreement contains a minimum standard of protection for patents, it contains no further standard as to what constitutes an effective sui generis system, nor does it mention UPOV. Therefore, WTO members that haven't acceded UPOV are not obliged to comply with UPOV provisions, and may prefer to develop their own sui generis system of protection. (4)

In member countries, the issue has been how to balance the interest of "breeders" and "farmers" while providing protection to new varieties of plants. The protection of plants 
varieties under patent would be the worst solution for developing countries, as patent is the most powerful mean of protection.

In most patent laws, in effect, there is no exception similar to the "breeder's exemption" under plant breeder rights regimes. Hence, the patentee may, in principle, prevent a third party from using the patented variety for further research and breeding. He could prevent, for instance, multiplication of the variety, even experimental purposes. The claims in a variety patent may cover inbred lines or hybrids; they may cover seeds or plants; and they may attempt to extent to progeny. Since a plant variety "is characterized by essentially all of its genes", the patenting of plant varieties may restrict the access to and use of the whole combination of genes that constitutes a variety, and prevent the development of new combinations of such genes.

The possibility of excluding plant varieties from patent protection as permitted under the TRIPs agreement and the previous resistance of many member countries to provide any protection at all in this field, will most likely result in either the adherence of those countries to the UPOV Convention or the creation of sui generis protection according to their own concepts.

\section{Duration of the Protection}

The evolution of breeder's rights, as exclusive rights, clearly shows that it is a form of intellectual property right. Thus similar to IPRs, breeder's rights are granted for a limited period of time, at the expiration of which it falls into the public domain. It has certain features in common with patents for industrial inventions, as both form of protection grants their holders a form of exclusive right to serve as an incentive to stimulate innovative activity. Under UPOV Convention 1978, the recommended minimum period of protection for plant varieties is fifteen years, computed from the date of issue of the title of protection, and less than eighteen years for vines, forest trees, fruit trees and ornamental trees. The duration of protection of breeder's right under the 1991 Act for plant varieties was extended to not less than twenty years from the date of the grant of the breeder's right, and for trees and vines the duration should not be less than twenty-five years.

\section{Developments of PVP Law in India \& Africa}

The case of plant variety protection in India and Africa is unique.(5) While Indian PVP legislation concurrently provides for farmers' rights and plant breeders rights, the Organization of African Unity (OAU) renamed as African Union w.e.f. $9^{\text {th }}$ July $2002-$ has evolved a model OAU Law which provide a basis for individual African countries to prepare their PVP legislations. Main features of Indian plant variety legislation and African OAU Model Law are discussed in below:

\section{Indian PVP Legislation $(6,7)$}

The Indian legislation known as 'Protection of Plant Varieties and Farmers' Rights Act, 2001' focuses to provide optimal protection for plant varieties, rights to farmers and breeders and to enhance and encourage the development and sustenance of new varieties of plants. The Act has many distinctive features. It maintains a balance between the rights of farmers and breeders by gratifying the farmers and local communities from the pool of National Gene Fund for their conservation, sustenance and development efforts and, at the same time, ensuring reward for innovation by granting plant breeders' rights. Due care of public interests will be taken care of through various provisions in governing laws as compulsory licensing, non-registration of varieties which affect public order and morality and are injurious to human, animal, plant life and health directly or indirectly. To ensure that modern breeding techniques, which use advanced technologies like biotechnology, are not misused, the Act prohibits registration of any variety which contains Genetic Use Restriction Technology (GURT). Hopefully this legislation sets landmarks which stimulate research and development in agriculture, health and environmental areas both in public and private sector by providing protection for plant varieties. However, the legislation has always a scope for further improvements and fine adjustments for better improvements to society. 
First, the Act envisages inviting claims for benefit sharing from any person/group of persons or non-governmental organizations (NGOs) after issuing the certificate of registration. These well-defined and precise provisions on benefit sharing should be spelt out clearly and accurately. It always depends on the extent of genetic material used and the proportion of benefits the breeder has to share with the public should be specified in the beginning itself to overcome technical issues. This sets as new era in development and will be helpful to remove the uncertainty in the minds of public and private seed companies, so that they can precisely earmark their $R \& D$ portfolio for the development and enhancement of new plant varieties and associated technology.

Second, the most important and technical issue in the act specifies that the breeder shall disclose to the farmers about the expected performance under given conditions of any propagating material of a registered variety. But if the variety or the propagating material does not perform as expected under given conditions, the farmers would have to approach the authority and the authority, after listening to both parties, shall decide about the problem concerned and approach the amount of compensation.

Third, the act provides a separate route for registration of essentially derived varieties (EDVs). The Authority, not the Registrar of Plant Varieties, will consider about granting the certificate of registration for EDVs. A basic approach should be applied for registration of EDVs through the same channel as other new varieties of plants. EDVs are transgenic crops which are alike to the original variety except the act of origin. Instead of providing them separate channel for these varieties, the registration of EDVs through the same route should be allowed. There is a need to take effective measures for environmental impact assessment of EDVs before they go to the farmers' fields.

Lastly, this legislation provides the scope for farmers being dragged into courts by the plant breeders.

\section{African Model Law on PVP}

Africa is the genetic source of a number of crop species. About 75 percent of tropical fodder grasses cultivated in the world and 40 percent of legumes originated from Africa. Furthermore, a number of African crops are specific to the continent, such as Tef, Ensete, Qat, Shea butter, African locust, Cola, Bambara nut, Se-same (in part), Nugh, Gombo, Karka-deh and many others. Recognising the need to conserve the rich biodiversity of the continent, the OAU embarked on a process to assist African countries in fulfilling their obligations to the Convention on Biological Diversity and TRIPs Agreement of the WTO. The proposal resulted in the expansion of a Model Law known as "Model Legislation on the Protection of the Rights of Local Communities, Farmers and Breeders, and for the Regulation of Access to Biological Resources" in 1997. The OAU Heads of State, in July 1998, endorsed the Model Law and recommended that it become the basis of all national laws on the matter across Africa. (8)

The Model Law has four components;

1. Access to biological resources,

2. Community rights,

3. Farmers' rights and

4. Plant breeders' rights.

The law mainly aims at ensuring preservation, quality assessment and sustainable use of biological resources, including agricultural genetic resources, and corresponding information and technologies in order to uphold and improve their diversity as a means of sustaining all life support systems. It recognises that all forms of life are the basis for human survival and growth and, therefore, patenting of life or the exclusive requisition of any life form violates the essential human right to life. A distinctive feature of the legislation is that it has well-built support to the role that women play in the generation, preservation, and sustainable utilization of biological diversity and associated knowledge and calls for their full contribution at all steps of policy-making and functioning in relation to biological diversity, and allied knowledge and technologies. 
Law has adequate provisions for safety measures of farmers' breeds and seeds according to the criteria based on habitual practices. Farmers have right and obligations to save, use, multiply and sell seeds, with the limitation that sale of material owned by the farmers should not be on a business-related scale. (9) It recognises and appreciates intellectual property rights of breeders over new varieties that are distinct, stable and adequately homogenous. Breeders' Rights on a new plant variety are subject to restriction with the objective of protecting food security, health, biological diversity and any other requirements of the farming community for propagation material of a particular variety. Thus breeders' rights are subordinate to farmers' rights.

\section{Advantages of PVP Law for developing Countries}

- PVP law aims to promote international trade in agriculture by opening developing country markets for hybrids and better quality plant varieties and help in reducing deficiencies in agriculture practices in these countries. (10)

- Plant variety protection aids in economic development of the country since it encourages foreign investments by safeguarding high risk investments of the foreign breeders. (11)

- The legal protection offered by intellectual property rights in the form of plant variety protection provides incentives for private sector and promotes its involvement in the development of new plant varieties.

- The only solution to the continuously rising problems of "food security" and "loss of agriculture land" in the developing countries is to increase the "productivity per unit area". PVP law help in this direction by promoting research for the development of modified varieties with improved nutritional value. (12)

- PVP law provides incentives to domestic plant breeders for their innovation and compensating for their investments.

\section{Conclusion:}

Developing countries are facing a tough battle against time in safeguarding their natural resources under changed global environment. The case of plant variety legislation in India and Africa is unique because in both the cases the relevant legislations provide for farmers' rights and plant breeders rights, simultaneously.

The Indian PVP legislation balances rights of the farmers and breeders by rewarding the farmers and local communities from the pool of National Gene Fund for their conservation and development efforts and, at the same time, ensuring reward for innovation by granting plant breeders' rights.

The OAU Model Law aims at ensuring conservation, evaluation and sustainable use of biological resources, including agricultural genetic resources, and knowledge and technologies in order to maintain and improve their diversity as a means of sustaining all life support systems. Though it provides a model framework to protect farmers' rights as well as breeders' rights', it has been criticized by the UPOV and WIPO who consider that UPOVtype system alone effectively fulfils TRIPS Article 27.3(b) requirement.

The obligation to introduce plant varieties protection in developing countries is a novelty for all. It will bring fundamental changes to their legal system and constitute significant departure from previous practices which generally empathized the free sharing of knowledge at all levels.

\section{Conflicts of Interest: None}

The views expressed in this review are the authors' personal opinions and views. They do not represent the official policy, views or position of any institutions with which the authors are affiliated.

\section{References:}

1. Langford J. Intellectual Property Rights: Technology Transfer and Resource Implications. Amer. Jn. Agri. Econ. 1997; 79(5): 1576- 83.

2. UPOV Convention: International union for the protection of new varieties of plants [Internet]. Geneva: 1991 [updated 2010 April 20; cited 2013 
Oct 16]. Available from: http://www. upov.int/en/ publications/conventions/1991/act1991.htm.

3. Lesser WH. Equitable patent protection in the developing world: Issues and opportunities. Eubios Ethics Institute. Tskuba, Japan; 1991.

4. Gahukar RT. Intellectual Property Rights and the management of Traditional Knowledge in Indian agriculture. J. of Knowledge Management Practice. 2010 Jun;11(2).

5. Commission on Intellectual Property Rights (CIPR).Integrating Intellectual Property Rights and Development Policy. London: CIPR; March 2010.

6. GRAIN. International agency for development. [Internet]. Spain: GRAIN's coordination office; 2010 [cited 2010 April 23]. Available from: www.grain.org/publications/oau-en.cfm.

7. Department of Agriculture And Cooperation. The Gazette of India. Protection of Plant Varieties and Farmers' Rights Act, 2001 [Internet]. India: Ministry of Law, Justice and Company affairs; 2001 [cited 2010 July 25]. Available from: http://agricoop.nic.in/PPV\&FR\%20Act,\%202001. pdf.
8. GRAIN. Landmark decision for african indigenous communities. [Internet]. Spain: GRAIN's coordination office; 2010 [cited 2010 April 25]. Available from: www.grain.org/publications/pvp-south-upoven.cfm.

9. Algeria. OAU model law. African Model Legislation for the Protection of the Rights of Local Communities, Farmers and Breeders, and for the Regulation of Access to Biological Resources. Algeria: Rights of Communities, Farmers, Breeders, and Access to Biological Resources; 2000.

10. Dang R, Goel C. Sui Generis Plant Variety Protection: The Indian Perspective. Am. J. Eco. and Bus. Admin. 2009; 1 (4): 303-12.

11. Verkey E. Law of Plant Varieties Protection. Allahabad: Eastern Book Company; 2007. p. 13.

12. Cullet P. Intellectual Property Protection and Sustainable Development. Delhi: LexisNexis Butterworths; 2005. p. 202-203. 